ISSN 1424-8220

www.mdpi.com/journal/sensors

Correction

\title{
Publisher's Note - Pagination Error
}

\section{Shu-Kun Lin}

Molecular Diversity Preservation International (MDPI), Kandererstrasse 25, CH-4057 Basel,

Switzerland; E-mail: lin@mdpi.org

Published: 4 June 2009

Publisher's Note added on 4 June 2009: There is a pagination error in Sensors 2009, 9(6) with page 4271 missing. Thus, page 4271 is taken as a blank page.

(C) 2009 by the authors; licensee Molecular Diversity Preservation International, Basel, Switzerland. This article is an open-access article distributed under the terms and conditions of the Creative Commons Attribution license (http://creativecommons.org/licenses/by/3.0/). 